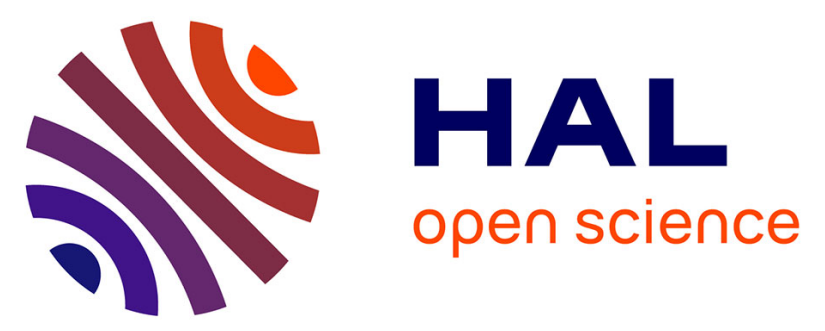

\title{
Effects of organic enrichment on nematode assemblages in a microcosm experiment
}

\author{
Maickel Armenteros, José Andrés Pérez-García, Alexei Ruiz-Abierno, Lisbet \\ Díaz-Asencio, Yusmila Helguera, Magda Vincx, Wilfrida Decraemer
}

\section{To cite this version:}

Maickel Armenteros, José Andrés Pérez-García, Alexei Ruiz-Abierno, Lisbet Díaz-Asencio, Yusmila Helguera, et al.. Effects of organic enrichment on nematode assemblages in a microcosm experiment. Marine Environmental Research, 2010, 70 (5), pp.374. 10.1016/j.marenvres.2010.08.001 . hal-00631696

\section{HAL Id: hal-00631696 https://hal.science/hal-00631696}

Submitted on 13 Oct 2011

HAL is a multi-disciplinary open access archive for the deposit and dissemination of scientific research documents, whether they are published or not. The documents may come from teaching and research institutions in France or abroad, or from public or private research centers.
L'archive ouverte pluridisciplinaire HAL, est destinée au dépôt et à la diffusion de documents scientifiques de niveau recherche, publiés ou non, émanant des établissements d'enseignement et de recherche français ou étrangers, des laboratoires publics ou privés. 


\section{Accepted Manuscript}

Title: Effects of organic enrichment on nematode assemblages in a microcosm experiment

Authors: Maickel Armenteros, José Andrés Pérez-García, Alexei Ruiz-Abierno, Lisbet Díaz-Asencio, Yusmila Helguera, Magda Vincx, Wilfrida Decraemer

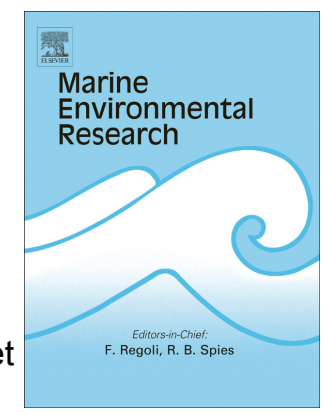

PII:

$$
\text { S0141-1136(10)00116-9 }
$$

DOI:

$$
\text { 10.1016/j.marenvres.2010.08.001 }
$$

Reference: MERE 3467

To appear in: Marine Environmental Research

Received Date: 3 March 2009

Revised Date: 12 August 2010

Accepted Date: 13 August 2010

Please cite this article as: Armenteros, M., Pérez-García, A., Ruiz-Abierno, A., Díaz-Asencio, L., Helguera, Y., Vincx, M., Decraemer, W. Effects of organic enrichment on nematode assemblages in a microcosm experiment, Marine Environmental Research (2010), doi: 10.1016/j.marenvres.2010.08.001

This is a PDF file of an unedited manuscript that has been accepted for publication. As a service to our customers we are providing this early version of the manuscript. The manuscript will undergo copyediting, typesetting, and review of the resulting proof before it is published in its final form. Please note that during the production process errors may be discovered which could affect the content, and all legal disclaimers that apply to the journal pertain. 


\section{Research article}

Title: Effects of organic enrichment on nematode assemblages in a microcosm experiment

Authors: Maickel Armenteros ${ }^{1,2}{ }^{*}$; José Andrés Pérez-García ${ }^{1}$; Alexei Ruiz-Abierno; Lisbet Díaz-Asencio ${ }^{3}$; Yusmila Helguera ${ }^{3}$; Magda Vincx²; Wilfrida Decraemer ${ }^{4,5}$

\section{Addresses:}

${ }^{1}$ Centro de Investigaciones Marinas, Universidad de La Habana, 16 \# 114, CP 11300, Playa, Habana, Cuba.

${ }^{2}$ Marine Biology Section, Ghent University, Krijgslaan 281 S8, B9000, Ghent, Belgium

${ }^{3}$ Centro de Estudios Ambientales de Cienfuegos, Ministerio de Ciencia, Tecnología y Medio Ambiente, Carretera a Castillo de Jagua km $1 \frac{1}{2}$, CP 59350, Cienfuegos, Cuba.

${ }^{4}$ Royal Belgian Institute of Natural Sciences, Vautierstraat 29, B1000, Brussels, Belgium.

${ }^{5}$ Nematology Section, Ghent University, Ledeganckstraat 35, B9000, Ghent, Belgium.

${ }^{*}$ Corresponding author 


\section{Abstract}

Marine nematodes from subtidal tropical sediments of Cienfuegos Bay were subjected to organic enrichment in a microcosm experiment for 32 days. Nematode abundance and diversity decreased, and the taxonomic and trophic structure was altered. The results suggested that the nematodes were not food limited in the microcosms or in their natural environment. Chemical stressors such as ammonia and hydrogen sulfide derived from reduced conditions in sediments may be important factors affecting the assemblages. Hypoxic conditions occurred in all experimental units, as well as in the field, suggesting a nematode assemblage adapted to naturally enriched sediments. However, tolerant species showed a grade of sensitivity to reduced conditions. In agreement with the model by Pearson and Rosenberg (1978), we predict that further organic enrichment in sediments from Cienfuegos Bay may cause a phase shift into a strongly depleted benthic fauna and reduced conditions in water and sediments.

Keywords: nematodes, organic enrichment, microcosm, hypoxia, tropical, community composition, effects-community, Caribbean Sea. 


\section{Introduction}

Organic enrichment is an important ecological process in marine sediments (Kelly and Nixon, 1984) and in coastal ecosystems it is related to the presence of fine sediment, a low hydrodynamic regime and low dissolved oxygen (Snelgrove and Butman, 1994). Benthic assemblages in those environments are dominated by deposit-feeding organisms that make use of both particulate organic matter and the associated bacterial biomass. The benthic response to organic enrichment has been documented by Pearson and Rosenberg (1978); their model clearly describes the ecological succession that takes place in soft bottoms when organic load increases and it has been widely applied. Particularly, in sediments where heavy organic pollution exist almost no macrofauna can be found and nematodes are the dominant metazoans (Pearson and Rosenberg, 1978).

Free-living marine nematodes are the most abundant deposit feeders and play an important role in transforming organic matter in marine sediments (Findlay and Tenore, 1982; Li et al., 1997; Piepenburg et al., 1997). The content of organic matter can partially explain the spatial patterns of distribution of free-living nematodes in some habitats (e.g. Ólafsson and Elmgren, 1997; Schratzberger et al., 2006). Therefore, further investigations on the relationships between organic content and nematodes and the mechanisms underlying them are needed. At least several ecological factors such as type of habitat, origin of organic input and intensity of human disturbance affects these relationships (Schratzberger et al., 2008). 
Two previous studies (Armenteros et al., 2009; Pérez-García et al., 2009) on the distribution of nematode assemblages in several sites in the basin found considerable spatial heterogeneity on the scale of a few meters and that the dominant nematode species were tolerant of organic enrichment, such as Sabatieria pulchra and Terschellingia longicaudata. The spatial patterns were linked to organic matter and heavy metal content in sediments and to water depth. These correlations suggested alternative ecological mechanisms that could determine the distribution of nematode assemblages, for instance: toxic effects, limitation in benthic primary productivity, and hydrodynamic regime affecting both dispersion and transport of sediment. Since no causative mechanism could be clearly identified in these field studies, an experimental approach could help to obtain a more comprehensive idea of the ecological factors that drive the distribution of the assemblages.

Organic pollution of water and sediments is one of the main stressors in the marine environment (Diaz and Rosenberg, 2008) and it is an important disturbance in semienclosed basins due to the limited water renewal time of these ecosystems (Urban et al., 2009). Cienfuegos Bay is a semi-enclosed shallow bay in the Caribbean Sea, dominated by organically enriched, muddy bottoms, although mangroves, seagrass meadows and beaches also occur within the bay. Additionally, heavy metal and hydrocarbon pollution is widespread in the sediments of the bay from industrial activities and human settlements in the basin (Tolosa et al., 2009). Increasingly development of the petroleum-related industrial activities have been occurring in Cienfuegos Bay, including refinement of crude petroleum, storage and transport of gasoline and diesel fuel, and processing of derivates like plastics. That is why an 
increase of the risk of deleterious effects of organic enrichment is expected on this ecosystem due to diffuse and/or point oil spills which could originate from the petroleum industry. In this context, an experimental approach to test the effects of a putative increase of the organic loading on the benthic assemblages is very pertinent.

Effects of organic enrichment on meiofauna and/or nematodes in experimental microcosms have been analyzed by Sandulli and Nicola-Giudici (1989), Sundbäck et al. (1990), Webb (1996), and Schratzberger and Warwick (1998); all of these studies were carried out in temperate regions. Extrapolation of these results to tropical regions remains inconclusive because at least two factors are different (see Alongi, 1990 for review): (1) high irradiance throughout the year leads to continuous high primary production, and (2) high temperature of shallow water enhances hypoxic conditions and stratification in the water column. In addition, a general lack of information on tropical ecosystems prevents across-region synthesis (Gray et al., 2002; Wu, 2002).

A study was then designed to test the effects of organic enrichment on nematode assemblages in microcosm ecosystems using sediment collected from Cienfuegos Bay. The aims of the experiment were twofold: to identify possible ecological mechanisms controlling the distribution of nematode assemblages in the ecosystem; and to show the possible effects of further organic enrichment due to pollution derived from industrial activities. We proposed, the following null hypothesis $(\mathrm{H} 0)$ : there will be no changes in the structure of assemblages in the treated microcosms compared to field and control samples; and an alternative hypothesis $(\mathrm{H} 1)$ : there will be changes in the structure in response to enrichment. 


\section{Materials and methods}

\subsection{Field site}

Surface sediments were collected subtidally in Cienfuegos Bay, Cuba, Caribbean Sea (N 2207.970' W80²9.824) in May 2007. The site was previously included in a study of spatial distribution of nematodes (station 5 in Pérez-García et al., 2009). The study site is characterized by: muddy sediments ( $87 \%$ silt/clay), high organic content (47.3 $\mathrm{mg} \mathrm{C} \mathrm{g}^{-1} \mathrm{DW}$ ), $12 \mathrm{~m}$ depth, marine salinity (annual range: $34-37$ ), and tropical temperature (annual range: $24-30^{\circ} \mathrm{C}$ ). Historical data (1991-2001) of dissolved oxygen in the bottom waters of this station was used for further comparison with values in microcosms. Only oxygen measures clearly belonging to wet season (when sediment was collected for the experiment) were selected for comparisons due to the seasonal fluctuations.

2.2 Collection and manipulation of sediment

Five plastic cores (2.6 cm internal diameter) were taken to $6 \mathrm{~cm}$ depth in the sediment: three for the description of the community structure and two for the estimation of organic content; all of these samples were labeled as field control. The same day and site, 5 - $10 \mathrm{~m}$ apart, using SCUBA diving we carefully collected 
approximately $15 \mathrm{I}$ of surface sediment (top $3-4 \mathrm{~cm}$ ) in glass flasks. The fresh sediment was transported to the lab, stored in two plastic containers with aeration for approximately $18 \mathrm{~h}$; thereafter, the sediment was gently homogenized with a plastic spoon and finally transferred to the experimental units. Before transference, four random aliquots (= small spoons) of sediment were checked for the presence of living (= moving) nematodes. As nematodes appeared alive and healthy, it was assumed that manipulation of the sediment had little impact on the survival of the nematodes.

\subsection{Microcosms}

Microcosms consisted of 500-ml glass flasks, and each microcosm was considered to be an independent experimental unit. Approximately the same amount of homogenized fresh sediment $(150-180 \mathrm{ml})$ was added to each microcosm resulting in a layer of sediment of $2.0-2.5 \mathrm{~cm}$ depth and surface area of ca. $20 \mathrm{~cm}^{2}$. Care was taken to avoid the inclusion of large macrofaunal animals (e.g. polychaetes) into the microcosms. However, one week after the onset of the experiment, holes and some bioturbation activity was evident in the microcosms. The flasks were carefully filled with filtered seawater and sealed with a $45 \mu \mathrm{m}$ mesh to prevent upward migration of meiofauna. The 72 microcosms used in the experiment were placed into four tanks of 50 I capacity (18 per tank), maintained in darkness to avoid primary production; and left for $48 \mathrm{~h}$ for acclimatization before application of treatments. The tanks were 
completely filled with seawater and connected to the closed seawater circuit of the laboratory; this included the use of a biological filter, the control of water temperature $\left(27{ }^{0} \mathrm{C}\right.$ at noon), saturation of dissolved oxygen (average $6.2 \pm 0.1 \mathrm{mg} \mathrm{O}_{2} \mathrm{I}^{-1}$ ) and constant salinity (36 ppt) for the duration of the experiment.

\subsection{Treatments}

Values of readily oxidizable organic matter (hereafter referred to as organic matter) of $50 \mathrm{mg} \mathrm{C} \mathrm{g}^{-1} \mathrm{DW}$ sediment (range: $44.5-61.8 \mathrm{mg} \mathrm{C} \mathrm{g}^{-1} \mathrm{DW} ; \mathrm{n}=8$ ) at the site where sediment was collected indicate organic enrichment. Unfortunately, the rate of natural input of organic matter to sediments is largely unknown for similar tropical ecosystems. Even in more studied ecosystems (i.e. temperate estuaries) estimates of organic input to sediments are not well documented and often underestimated (Kendall et al., 1995). Other microcosm studies have applied doses of added organic matter as high as 200 or $400 \mathrm{~g} \mathrm{C} \mathrm{m}^{-2}$, sometimes without responses of nematode assemblages (e.g. Austen and Warwick, 1995).

Therefore, in order to induce a significant disturbance on our microcosms we choose three treatments: 1) control: without addition of organic matter; 2) medium: addition of $25 \mathrm{mg} \mathrm{C} \mathrm{g}^{-1} \mathrm{DW}$ sediment, equivalent to $50 \%$ of natural average organic content in sediment, ca. $400 \mathrm{~g} \mathrm{C} \mathrm{m}^{-2}$ sediment; and 3) high: addition of $50 \mathrm{mg} \mathrm{C} \mathrm{g}^{-1} \mathrm{DW}$, 
equivalent to an increase of $100 \%$ of natural average content, ca. $800 \mathrm{~g} \mathrm{C} \mathrm{m}^{-2}$ sediment. The organic matter was added as powder of Spirulina microalgae; the content of organic matter per weight of algae was determined (536 mg C g ${ }^{-1}$ Spirulina powder) by using the same technique as for the determination of organic content in sediments (see below). The averaged ( \pm SD) dry weight of sediment in each microcosm was assessed (103 $\pm 9 \mathrm{~g}$ ), and the quantity of Spirulina powder to add was calculated (medium treatment: $5 \mathrm{~g}$ of powder added; high treatment: $10 \mathrm{~g}$ added).

\subsection{Experimental design}

The microcosms were assigned to the tanks by using a systematic assignation in order to obtain a maximum of interspersion of treatments; i.e. each tank contained control and treatment microcosms. Within each tank the position of the microcosms was assigned at random. At day 0 , four microcosms (one per tank) were extracted and processed (control at day 0). After that, the treatments were applied: each microcosm was extracted from the tank, the previously weighted aliquot of Spirulina powder was added, the flask re-sealed and placed again into the tank.

At days 4,15 and 30, 18 microcosms ( 3 treatments $\times 6$ replicates) were extracted at random with the restriction that a balanced number of microcosms per tank should be left; i.e. no more than two microcosms belonging to a same treatment could be 
removed from the tank. From six replicated microcosms, four were taken for the analysis of meiofaunal community structure and two for the determination of the content of organic matter. At day 30 the content of dissolved oxygen in the water inside the microcosms was measured.

2.6 Processing of samples

The content of each microcosm was sieved over a $45-\mu \mathrm{m}$ mesh sieve using filtered water. Meiofauna was sorted from sediment by flotation in a high density solution of

commercial sugar dissolved in water $\left(1.17 \mathrm{~g} \mathrm{~cm}^{-3}\right)$; the sorting efficiency of meiofauna using this technique is ca. $95 \%$ in our lab (Armenteros et al., 2008). Sorted meiofauna were counted under an stereomicroscope (36x) by using a counting dish, and 50 nematodes (when available) from each sample were removed for identification. Nematodes were mounted on microscope slides after the procedure by Vincx (1996) and identified to species level by using the pictorial keys by Platt and Warwick (1983, 1988), Warwick et al. (1998) and the NeMys Database (Deprez et al., 2007).

Concentration of readily oxidizable organic matter in sediment was determined by the modified Walkley-Black wet titration method (Loring and Rantala, 1992) by using oxidation with $\mathrm{K}_{2} \mathrm{Cr}_{2} \mathrm{O}_{7}$ and $\mathrm{H}_{2} \mathrm{SO}_{4}$. Concentration of dissolved oxygen in the water inside the microcosms ( $1-2 \mathrm{~cm}$ above sediment) was measured with a Hanna DO 
probe (accuracy $0.01 \mathrm{mg} \mathrm{O}_{2} \mathrm{I}^{-1}$ ). Additionally, a time series of dissolved oxygen in the bottom water was included for comparison with experimental units; the data came from the same station where sediment was collected and in the same weather season (wet).

\subsection{Measures of assemblages}

Traditional measures of structure of assemblages (i.e. abundance and number of species of nematodes) were determined. Each nematode species was classified into a scale of coloniser/persister (c-p value) according to several aspects of the life-trait after Bongers (1990) and Bongers et al. (1991). The maturity index of the community was calculated on the basis of the score in the c-p scale. Nematode species were assigned to feeding types according to Wieser's (1953) classification based on the morphology of the buccal cavity: selective deposit feeders (1A), non-selective deposit feeders (1B), epigrowth feeders (2A) and predator/omnivores (2B). The percentage of contribution of each feeding type to the total abundance was calculated for each sample. The four percentages (i.e. four feeding types) were pairwise significantly correlated each other; therefore only the most variable feeding type (non-selective deposit feeding, 1B) was subjected to statistical analysis because it putatively contains more interpretable information. 


\subsection{Data analysis}

Multi- and univariate techniques were used for data analysis using the software PRIMER 6.0.2 (Clarke and Gorley, 2006) and STATISTICA 6.0 from StatSoft. We tested the existence of statistical differences in six variables: organic matter, dissolved oxygen, number of nematodes, number of species, maturity index and percentage of $1 \mathrm{~B}$ nematodes. Two graphical methods were performed before the application of a statistical test in order to know if data fulfil the premises of parametric analysis: scatter plots of mean versus standard deviation; and residual versus predicted mean. If needed, data were transformed and re-checked to know if parametric assumptions were applicable. Two types of comparisons were performed due to the fact that a full crossed design treatment $x$ time could not include the field samples (no time).

(i) Comparisons between control groups in order to assess the "microcosm effect" using a one-way ANOVA with five levels: field control, microcosm controls at days 0 , 4, 15, and 30. If ANOVA was significant, two planned comparisons using least square means (t-test) were performed: field versus day 0 to test differences between natural environment and experimental conditions; and day 0 versus 30 to test the temporal changes in the microcosm controls. The organic matter content was not measured at day 0 , therefore the ANOVA levels were four and the following planned comparisons were performed: field versus day 4 , and day 4 versus 30 . The dissolved oxygen was measured only at day 30 , so the comparison was done by means of one-way ANOVA 
between treatments with five levels: field, tank, control, treatment medium, treatment high.

(ii) Two-way crossed ANOVA was carried out in order to compare: treatment (main factor, 3 levels: control, medium, high), time (main factor, 3 levels: 4, 15, 30 days) and their interaction.

Non-parametric analysis of similarity (ANOSIM) was employed for testing differences in multivariate structure of assemblages. Data were square-root transformed for down weighting the contribution of dominant species to structure. Similarity matrices were built by using Bray-Curtis similarity index and they were used for the ANOSIM hypothesis test and for the numerical ordination of samples by non-metric multidimensional scaling. The SIMPER procedure was applied to look for species which contribute the most to find out similarity/dissimilarity across treatments and/or time.

\section{Results}

3.1 Visual description of microcosms

Clear changes in sediment and overlying water were observed in microcosms along the duration of the experiment. Control microcosms were apparently stable during the 
32 days of the study: with clear water, a relatively thick oxidized layer of sediment (ca. $5 \mathrm{~mm}$ ) and presence of mounds and holes, presumably due to the activity of the small macrofauna. Two to three days after the addition of organic matter, treated microcosms showed a gradual trend of change for both sediment and water. At day 30 , all treated microcosms showed high turbidity, smell of hydrogen sulfide, blackening of sediment and presence of mats (presumably bacteria) on the watersediment interface.

\subsection{Abiotic factors}

There were differences in the log-transformed values of organic matter among field and microcosm controls (one-way ANOVA, $F_{3,4}=6.0, p=0.06$ ). Planned contrasts indicated significant differences between field and day $4\left(t_{2,4}=-3.8, p=0.02\right)$ suggesting higher levels of organic matter in the field. No significant differences between controls at day 4 and $30\left(t_{2,4}=-0.74, p=0.5\right)$ were detected; this indicates that levels of organic enrichment were stable in control microcosms (Figure 1). There were differences among treatments in the log-transformed values of organic matter (two-way ANOVA, $\left.F_{2,9}=235.9, p<0.001\right)$ but there were neither among days $\left(F_{2,9}=\right.$ $0.5, p=0.6)$ nor in the interaction $\left(F_{4,9}=0,9, p=0.6\right)$. This indicated that the treatments were effective, thus increasing the amount of organic matter in microcosms and that the organic content was constant throughout the experiment (Figure 1). 
A comparison of values of dissolved oxygen among treatments (at day 30) and field did not show statistical differences (one-way ANOVA, $F_{3,36}=1.64, p=0.20$ ). Measurements of dissolved oxygen indicated hypoxic conditions within the experimental units, with mean values less than $2 \mathrm{mg} \mathrm{O}_{2} \mathrm{I}^{-1}$; the field measurements showed a larger variability (Figure 1).

3.3 Abundance, number of species and maturity index

Thirty six species of free-living marine nematodes were recorded in our study (Table 1). A comparison of univariate measures of assemblages between field and control samples at day 0 could indicate how much the assemblages in the experimental conditions mimic the ones in the natural environment (Table 2, one-way ANOVA). There were significant differences in the log-transformed number of nematodes. Planned comparisons did not show any difference between field and control microcosms at day $0\left(\mathrm{t}_{2}, 38=0.6, \mathrm{p}=0.6\right)$, but they revealed significant differences between control microcosms at days 0 and $30\left(t_{2,38}=4.1, p<0.001\right)$ with a lesser number of nematodes in controls at the end of the experiment (Figure 2). The number of species showed significant differences; but the post hoc comparisons detected differences neither between field and control microcosms at day $0\left(t_{2,38}=-1.3, p=\right.$ $0.2)$ nor between control microcosms at day 0 and $30\left(t_{2,38}=1.2, p=0.2\right)$. 
The maturity index showed significant differences among field and controls (Table 2); however, the post hoc comparisons could not detect significant differences between field and control microcosms at day $0\left(t_{2,38}=-1.4, p=0.16\right)$, and between days 0 and $30\left(t_{2,38}=-1.84, p=0.07\right)$. Percentage of non-selective deposit feeding nematodes showed significant differences between field and control samples (Table 2). Planned post hoc comparison indicated no differences between field and control at day $0\left(t_{2,38}\right.$ $=0.88, p=0.4)$, but they showed significant differences between controls at day 0 and $30\left(t_{2}, 38=2.9, p=0.006\right)$. In general, results of comparisons among controls suggest that univariate measures of nematode assemblages were similar in field and in control microcosms at day 0 . However, several measures of assemblages changed significantly at the end of the experiment in comparison with day 0 , indicating that experimental conditions affect the existence of the assemblages in enclosed conditions (i.e. microcosm effect). ( I suspect that the oxygen supply to the micrcosms through newal by water flow was less than that in the field)

A two-way crossed ANOVA for comparison among treatments (three levels: control, medium and high) and times (three levels: days 4, 15 and 30) shows the effects of the treatment itself on univariate measures of assemblages, but also about possible interaction. The results showed significant differences of log-transformed nematode abundance in factors: treatment, time and treatment $x$ time (Table 2). A Tukey's posthoc test detected significant differences among three groups of mean values: highest abundance (controls and medium treatment at day 4), intermediate abundance (medium treatment at days 15 and 30 , and high treatment at 15), and lowest abundance (high treatment at day 30) (Figure 2). 
The number of species was different among times, but no significant change was observed among treatments, neither in the interaction (Table 2). A Tukey's post-hoc comparison indicated that samples from day 30 had a significantly lower number of species than at days 4 and 15 (Figure 2). The maturity index showed significant differences in factors time and treatment, but not in the interaction (Table 2). The maturity index was higher in medium and high treatments at day 30 , but for the controls no difference was observed (Figure 2).

3.4 Multivariate species composition of assemblages

Two different comparisons were carried out on the basis of multivariate composition of assemblages using the ANOSIM procedure: (i) one-way comparison of field versus control samples at several days (five levels: field, $0,4,15,30$ days); (ii) two-way crossed comparison of treatments (control, medium, high) and times (4, 15 and 30 days).

The field and control samples showed significant differences (ANOSIM, global test, $R$ $=0.49, \mathrm{p}=0.001 ; 999$ permutations). Most of the pair-wise comparisons between controls showed significant differences in the multivariate structure with R-values greater than 0.5 ; exception was control 0 versus control $4(R=0.22, p=0.17,35$ perm.). This suggests the existence of a microcosm effect changing the structure of nematode assemblages. However, in the ordination, the pattern of dispersion among 
control samples is not so clear, and field samples showed the highest dispersion in the plot (Figure 3).

The SIMPER procedure indicated that the same species contribute to similarity within groups of samples: Terschellingia longicaudata, Metalinhomoeus filiformis, Sabatieria pulchra, and Terschellingia gourbaultae. Differences among groups were accounted by the presence/absence of rare species.

Significant differences were detected among controls at different times $(R=0.47 ; p=$ $0.001 ; 999$ perm), indicating the presence of a microcosm effect. The differences among controls at day 0 and controls at subsequent times are mainly related to a decrease of abundance of some species such as Spirinia parasitifera, Metalinhomoeus filiformis and Terschellingia communis (Table 1).

The two-way crossed ANOSIM indicated significant differences among treatments in the multivariate structure of assemblages $(R=0.75 ; p=0.001 ; 999$ perm $)$ and among times $(R=0.82 ; p=0.001 ; 999$ perm). All pair-wise comparisons (using 999 permutations) were significant at 0.05 probability level, and R-values were higher than 0.5. However, the ordination of the samples (Figure 3) and the absolute values of $R$ statistic suggest an interaction between treatment and time.

In general, a reduction in the abundance of all species at days 15 and 30 was observed, although it was more pronounced in the treatment with high doses of organic matter (Table 1). The dominant species were the same in the field control as in microcosm controls. However, three of the four dominant species responded differently to the treatment over time (Table 1). The abundance of Spirinia parasitifera 
did not change upon addition of organic matter. Terschellingia longicaudata and Sabatieria pulchra showed a similar dominance in controls (days 0 and 4) and field; however, the depletion was stronger for the latter being nearly absent at day 30. T. longicaudata persisted in all microcosms even in high doses of organic matter. Other dominant species such as Cienfuegia cachoi, Metalinhomoeus filiformis, and Terschellingia gourbaultae were capable of persisting in treated microcosms, although with decreased abundance in regard to controls.

3.5 Trophic structure of assemblages

The classification of nematode species into feeding types allowed testing the effects of organic enrichment on trophic structure of assemblages. The abundance of nonselective deposit feeding nematodes (1B) among field samples and controls at day 0 did not differ significantly. Also the contribution of 1B type among controls at the four times was statistically non-significant (Table 2). However, the percentage of $1 \mathrm{~B}$ type showed significant differences among treatment, time and interaction treatment $\mathrm{x}$ time (Table 2). There was a clear reduction of nematodes belonging to $1 \mathrm{~B}$ type in microcosms subjected to medium and high doses of organic matter at days 15 and 30 from the onset of the experiment (Figure 4). This was related to the disappearance of Sabatieria pulchra, the most abundant species of feeding type 1B at day 30. 


\section{Discussion}

The integration of the results leads us to reject the null hypothesis of no changes in the structure of nematode assemblages subjected to experimental treatments. Therefore, we will discuss our findings, in the following order, (i) the validity of our experimental setting, (ii) the possible explanations of the obtained results, and (iii) the extrapolation of data from the experiment to nature.

4.1 Validity of the experimental setting

The changes in the amount of organic matter in the microcosms suggest some loss from the particulate phyto-detritus pool due to mineralization and leaching as dissolved carbon into overlying water (Webb, 1996). The concentration of dissolved oxygen in microcosms towards the end of the experiment was close to the recorded data from bottom water in the field; however, higher variability existed in data from the field due to the natural variability of dissolved oxygen and the relatively long period covered $(1991-2001)$. We consider the experimental set-up as successful in recreating an organically enriched environment although logical differences still remains compared to the field conditions. 
Changes observed in nematode abundance, and also in the multivariate structure of assemblages, indicated the existence of a "microcosm effect". Such an effect was recorded also by Sandulli and Nicola-Giudici (1989), and Schratzberger and Warwick (1999). The observed changes can be explained by the collection of surface sediment where nematodes are concentrated (thus higher abundance in microcosms) and due to the homogenization of sediment prior to setting of microcosms (thus lower variability in assemblage structure). Only four species out of 36 recorded from the field were not recorded in the microcosms, suggesting a good representation in the experimental conditions of the real diversity in nature.

The experimental set-up probably amplified the effects of treatments because the stagnant conditions avoid the exchange of water and replenishment of sediment (Sundbäck et al., 1990). However, interpretable results can still be obtained from the analysis of these laboratory communities, since important features of communities remain the same between field and control samples.

4.2 Possible explanations of the results

Apparently, negative species interactions were not exacerbated in the control microcosms; although evidence of significant interactions (i.e. predation and interference competition) with macrofauna has been recorded in comparable experiments (e.g. Widbom and Elmgren, 1988). The pool of particulate organic matter 
in sediments was large enough for the maintenance of nematode assemblages in control microcosms along the 32 days of the experiment.

Because the dominance of deposit feeding nematodes in the sediments from Cienfuegos Bay (Pérez-García et al., 2009) and the short generation time of some opportunistic species (Heip et al., 1985; Moens and Vincx, 2000) a positive response could be expected to the addition of phyto-detritus despite of the general deleterious effects of the organic enrichment. However, a sharp decrease in the nematode abundances was obtained. No evidence of feeding on the "fresh microbial mats" developed in the treated microcosms could be detected in our study in spite of the fact that deposit and epigrowth feeding nematodes can feed successfully on the microbial communities (Jensen, 1987b). This suggests that no food limitation occurs in the sediments, i.e., that organic matter was already available to nematode populations.

The increase of the maturity index as a response to organic load has been explained by Moreno et al. (2008) as the development of an assemblage characterized by species with low metabolic rate and tolerant to pollution. An artifact of the experimental microcosm could be the lack of recruitment of opportunistic species (Sandulli and Nicola-Giudici, 1989). The maturity index is strongly dependent on the species abilities as colonizers, so in this kind of enclosed system its interpretation should be done with caution, since anomalous results can be obtained in comparison to field studies. 
Our results broadly agree with previous experimental studies about the effects of organic enrichment on nematodes and meiofauna despite the difference in habitats and regimes of primary production (Table 3); also results from field sites, reported negative effects of organic enrichment on nematodes (e.g. Mazzola et al., 2000; Sutherland et al., 2007). The mechanisms underlying the observed patterns in the mentioned studies have been the response of nematodes to hypoxic - reduced conditions in sediments and/or the synergistic effects of other stressors (e.g. metals or physical disturbances).

Based on our study, it is not possible to isolate any single factor causing the observed patterns. We would suggest that there were effects of chemical stressors related to reduced conditions in sediments, i.e. hypoxia, hydrogen sulfide and ammonia, which interact in a poorly known way and have deleterious effects on benthic assemblages (Gray et al., 2002). Particularly, confusion on effects of hypoxia and bacterial byproducts often occurs (Wu, 2002). Hypoxia was present in all treatments and also in the field controls, in similar levels, therefore we hypothesize that toxic bacterial byproducts (ammonia and hydrogen sulfide) would be more important stressors on assemblages than oxygen per se. Nematode assemblages can successfully cope with hypoxic and even temporal anoxic events using behavioral (e.g. migration to "oxygen islands" sensu Reise and Ax, 1979; Wetzel et al., 1995) and/or physiological mechanisms (e.g. symbiosis with bacteria, low metabolic rate).

The dominant nematode species in the assemblages from Cienfuegos Bay are Sabatieria pulchra, Spirinia parasitifera, Terschellingia communis, T. gourbaultae, and $T$. longicaudata. They have been recognized extensively as tolerant to a diversity of 
stressors in soft bottoms (Rzeznik-Orignac et al., 2003; Schratzberger et al., 2006; Steyaert et al., 2007). Physiological and behavioral adaptations of the named species to poor-oxygenated environment include a low respiratory rate and slow movements (Warwick and Price, 1979; Warwick and Gee, 1984). Deposition of insoluble metal sulphides in intracellular inclusions in the species Sabatieria wieseri and Terschellingia longicaudata has been suggested as a mechanism of detoxification of sulfide (Nicholas et al., 1987). We observed granules in the intestine of specimens from Cienfuegos Bay, which would perform this detoxification function but further research is needed to clarify this. Other strategy for detoxification in nematodes inhabiting thiobiotic habitats is a slender body shape which increase the body surface (Jensen, 1987a); however, the body shape was not related to the tolerance of nematodes in our experiment.

Our results suggest that $S$. pulchra is more sensitive to reduced conditions than Terschellingia longicaudata and Metalinhomoeus filiformis; the other dominant species, Spirinia parasitifera, showed a notable resistance to the effects of treatments. The species-specific response of nematode assemblages to organic enrichment has also been noted by Schratzberger et al. (2008); it means that not all species populations deplete at the same rate.

A further point to be discussed is concerning to the identity of species. The dominant morpho-species mentioned above are not only tolerant to a variety of disturbances; but rather they have been also recognized as cosmopolitans. However, morphologically cryptic species complexes have been identified for Terschellingia longicaudata (Bhadury et al., 2008) and possibly exist also for the widely distributed 
species Sabatieria pulchra and Spirinia parasitifera. Further research is necessary in order to understand the relationships between the ecological distribution and molecular identity of the nematode species.

\subsection{Extrapolation to field conditions}

Caution should be exercised in the extrapolation of results from laboratory experiments to larger spatial scale in the field because that is one of the main sources of misleading conclusions (Carpenter, 1996). However, the response of infauna to organic enrichment are governed primarily by the adaptations of species, thus extrapolation of responses from small-scale experiments to larger scale can be accepted (Zajac et al., 1998). We infer that in the muddy bottoms of Cienfuegos Bay the nematode assemblages are not food limited. A lack of positive response of nematode assemblages to food supply in organically enriched sediments has also been recorded by Moreno et al. (2008) in a similar environment. Probably, the nematofauna can use the relatively high pool of organic matter already present in the sediment either as dissolved carbon (Jensen, 1987b) or as particulate carbon (Rudnick, 1989).

The hypoxic conditions do not always lead to the production and accumulation of ammonium and hydrogen sulfide in water and sediments (Gray et al., 2002). In Cienfuegos Bay the hydrodynamic regime from waves and tidal currents and the 
intense photoautotrophic activity probably contribute to a decrease of the reduced conditions of sediments. Presence of mats (presumably cyanobacteria) on sediments has been observed at the station where sediment was collected in Cienfuegos Bay (M. Armenteros, pers. obs.). However, this phenomenon appeared to be highly patchy probably reflecting the spatially variable deposition of detritus from the water column (Levinton and Kelaher, 2004).

A detailed study on the distribution of hydrocarbons petroleum-derived in Cienfuegos Bay concluded that the basin is subjected already to moderate/high level of organic pollution (Tolosa et al., 2009). Previous studies about the spatial and temporal distribution of meiofaunal nematodes (Armenteros et al., 2009) and macrofauna (in preparation) suggest that the muddy bottoms in Cienfuegos Bay may suffer seasonal hypoxia with almost defaunation of macrofauna. This state was already described by Pearson and Rosenberg (1978) regarding to soft bottoms subject to moderate/heavy organic pollution. As our results suggest, even the tolerant nematode species naturally living in these sediments may be depleted if the organic load is considerably increased. We suggest that a further organic enrichment in the muddy areas of Cienfuegos Bay may cause a drastic phase shift towards strongly reduced sediments with plenty of heterotrophic bacteria and relatively few tolerant species of nematodes. Strong changes can be expected also in benthic metabolism in response to a putative increase of organic deposition (Kelly and Nixon, 1984).

\section{Conclusions}


(i) Nematode assemblages from naturally enriched sediments suffered deleterious changes when they were exposed to different loads of phyto-detritus in microcosms possibly due to the accumulation of byproducts of bacterial metabolism. Hypoxia per se probably was not the direct cause of depletion in the assemblages.

(ii) Dominant nematode species showed a different degree of sensitivity to reduced conditions, with Spirinia parasitifera as the least sensitive species, followed by Terschellingia longicaudata, Metalinhomoeus filiformis, and Sabatieria pulchra.

(iii) We predict a phase shift in sedimentary environment towards strongly reduced conditions and a depleted nematofauna if further high load of anthropogenic organic matter is added to these muddy bottoms.

\section{Acknowledgements}

We thank the staff of the Centro de Estudios Ambientales de Cienfuegos, Cuba for their support to this research, particularly Raúl Fernández-Garcés and Carlos Duarte for their help with the field work and Aniel Guillén for measurements of organic matter. Erik Perera and Germán Saavedra provided us facilities at their laboratory for the experimental set-up, and Sergio Hernández helped us with oxygen measurements. We also thank J.I. Hernández for English corrections. M. Armenteros 
received financial support from the International Foundation for Science (IFS/4004-1) and University of Ghent (Grant BOF 01W01607). The article was improved by the input of the editor Bob Spies and two anonymous referees; we acknowledge them.

\section{References}

Alongi, D.M. (1990). The ecology of tropical soft-bottom benthic ecosystems.

Oceanography and Marine Biology. An Annual Review, 28, 381-496.

Armenteros, M., Pérez-García, J.A., Pérez-Angulo, A., \& Williams, J.P. (2008).

Efficiency of extraction of meiofauna from sandy and muddy marine sediments.

Revista de Investigaciones Marinas. Universidad de La Habana, 29, 113-118.

Armenteros, M., Ruiz-Abierno, A., Fernández-Garcés, R., Pérez-García, J.A., DíazAsencio, L., Vincx, M., \& Decraemer, W. (2009). Biodiversity patterns of freeliving marine nematodes in a tropical bay: Cienfuegos, Caribbean Sea.

Estuarine, Coastal and Shelf Science, 85, 179-189.

Austen, M.C., \& McEvoy, A.J. (1997). The use of offshore meiobenthic communities in laboratory microcosm experiments: response to heavy metal contamination. Journal of Experimental Marine Biology and Ecology, 211, 247-261.

Austen, M.C., \& Warwick, R.M. (1995). Effects of manipulation of food supply on estuarine meiobenthos. Hydrobiologia, 311, 175-184. 
Austen, M.C., \& Widdicombe, S. (2006). Comparison of the response of meio- and macrobenthos to disturbance and organic enrichment. Journal of Experimental Marine Biology and Ecology, 330, 96-104.

Bhadury, P., Austen, M.C., Bilton, D.T., Lambshead, P.J.D., Rogers, A.D., \& Smerdon, G.R. (2008). Evaluation of combined morphological and molecular techniques for marine nematode (Terschellingia spp.) identification. Marine Biology, 154, 509-518.

Bongers, T. (1990). The maturity index: an ecological measure of environmental disturbance based on nematode species composition. Oecologia, 83, 14-19.

Bongers, T., Alkemade, R., \& Yeates, G.W. (1991). Interpretation of disturbanceinduced maturity decrease in marine nematode assemblages by means of the Maturity Index. Marine Ecology Progress Series, 76, 135-142.

Carpenter, S.R. (1996). Microcosm experiments have limited relevance for community and ecosystem ecology. Ecology, 77, 677-680.

Clarke, K.R., \& Gorley, R.N. (2006). Primer v6: User manual/tutorial. Plymouth: Primer-E, Ltd.

Deprez, T., \& all. (2007). NeMys. World Wide Web electronic publication. http://www.nemys.ugent.be , version (12/2008).

Diaz, R.J., \& Rosenberg, R. (2008). Spreading dead zones and consequences for marine ecosystems. Science, 321, 926-929.

Findlay, S., \& Tenore, K.R. (1982). Effect of a free-living marine nematode (Diplolaimella chitwoodi) on detrital carbon mineralization. Marine Ecology Progress Series, 8, 161-166. 
Gray, J.S., Wu, R.S., \& Or, Y.Y. (2002). Effects of hypoxia and organic enrichment on the coastal marine environment. Marine Ecology Progress Series, 238, 249-279. Gyedu-Ababio, T.K., \& Baird, D. (2006). Response of meiofauna and nematode communities to increased levels of contaminants in a laboratory microcosm experiment. Ecotoxicology and Environmental Safety, 63, 443-450.

Heip, C., Vincx, M., \& Vranken, G. (1985). The ecology of marine nematodes.

Oceanography and Marine Biology. An Annual Review, 23, 399-489.

Jensen, P. (1987a). Differences in microhabitat, abundance, biomass and body size between oxybiotic and thiobiotic free-living marine nematodes. Oecologia, 71, 564-567.

Jensen, P. (1987b). Feeding ecology of free-living aquatic nematodes. Marine Ecology Progress Series, 35, 187-196.

Kelly, J.R., \& Nixon, S.W. (1984). Experimental studies of the effect of organic deposition on the metabolism of a coastal marine bottom community. Marine Ecology Progress Series, 17, 157-169.

Kendall, M.A., Davey, J.T., \& Widdicombe, S. (1995). The response of two estuarine benthic communities to the quantity and quality of food. Hydrobiologia, 311, 207214.

Levinton, J., \& Kelaher, B. (2004). Opposing organizing forces of deposit-feeding marine communities. Journal of Experimental Marine Biology and Ecology, 300, $65-82$.

Li, J., Vincx, M., \& Herman, P.M.J. (1997). Carbon flows through meiobenthic nematodes in the Westerschelde Estuary. Fundamental and Applied Nematology, 20, 487-494. 
Loring, D.H., \& Rantala, R.T.T. (1992). Manual for the geochemical analysis of marine sediments and suspended particulate matter. Earth-Science Review, 32, 235283.

Mazzola, A., Mirto, S., La Rosa, T., Fabiano, M., \& Danovaro, R. (2000). Fish-farming effects on benthic community structure in coastal sediments: analysis of meiofaunal recovery. ICES Journal of Marine Sciences, 57, 1454-1461.

Moens, T., \& Vincx, M. (2000). Temperature and salinity constraints on the life cycle of two brackish-water nematode species. Journal of Experimental Marine Biology and Ecology, 243, 115-135.

Moreno, M., Ferrero, T.J., Gallizia, I., Vezzulli, L., Albertelli, G., \& Fabiano, M. (2008). An assessment of the spatial heterogeneity of environmental disturbance within an enclosed harbour through the analysis of meiofauna and nematode assemblages. Estuarine, Coastal and Shelf Science, 77, 565-576.

Nicholas, W.L., Goodchild, D.J., \& Steward, A. (1987). The mineral composition of intracellular inclusions in nematodes from thiobiotic mangrove mud-flats. Nematologica, 33, 167-179.

Ólafsson, E., \& Elmgren, R. (1997). Seasonal dynamics of sublitoral meiobenthos in relation to phytoplankton sedimentation in the Baltic Sea. Estuarine, Coastal and Shelf Science, 45, 149-164.

Pearson, T.H., \& Rosenberg, R. (1978). Macrobenthic succession in relation to organic enrichment and pollution of the marine enviroment. Oceanography and Marine Biology. An Annual Review, 16, 229-311.

Pérez-García, J.A., Armenteros, M., Díaz-Asencio, L., Díaz-Asencio, M., RuizAbierno, A., Fernández-Garcés, R., Bolaños-Alvarez, Y., \& Alonso-Hernández, 
C. (2009). Spatial distribution of nematode assemblages in Cienfuegos Bay (Caribbean Sea), and their relationships with sedimentary environment. Meiofauna Marina, 17, 71-81.

Piepenburg, D., Ambrose, W.G., Brandt, A., Renaud, P.E., Ahrends, M.J., \& Jensen, P. (1997). Benthic community patterns reflect water column processes in the Northern Water polynya (Greenland). Journal of Marine Systems, 10, 467-482.

Platt, H.M., \& Warwick, R.M. (1983). Free-living marine nematodes. Part I. British Enoplids. Cambridge: The Linnean Society of London and The Estuarine and Brackish-water Sciences Association.

Platt, H.M., \& Warwick, R.M. (1988). Free-living marine nematodes. Part II. British Chromadorids. Leiden: The Linnean Society of London and The Estuarine and Brackish-water Sciences Association.

Reise, K., \& Ax, P. (1979). A meiofaunal "thiobios" limited to the anaerobic sulfide system of marine sand does not exist. Marine Biology, 54, 225-237.

Rudnick, D.T. (1989). Time lags between the deposition and meiobenthic assimilation of phytodetritus. Marine Ecology Progress Series, 50, 231-240.

Rzeznik-Orignac, J., Fichet, D., \& Boucher, G. (2003). Spatio-temporal structure of the nematode assemblages of the Brouage mudflat (Marennes Oléron, France). Estuarine, Coastal and Shelf Science, 58, 77-88.

Sandulli, R., \& Nicola-Giudici, M. (1989). Effects of organic enrichment on meiofauna: A laboratory study. Marine Pollution Bulletin, 20, 223-227.

Schratzberger, M., Forster, R.M., Goodsir, F., \& Jennings, S. (2008). Nematode community dynamics over an annual production cycle in the central North Sea. Marine Environmental Research, 66, 508-519. 
Schratzberger, M., Warr, K., \& Rogers, S.I. (2006). Patterns of nematode populations in the southwestern North Sea and their link to other components of the benthic fauna. Journal of Sea Research, 55, 113-127.

Schratzberger, M., \& Warwick, R.M. (1998). Effects of the intensity and frequency of organic enrichment on two estuarine nematode communities. Marine Ecology Progress Series, 164, 83-94.

Schratzberger, M., \& Warwick, R.M. (1999). Differential effects of various types of disturbances on the structure of nematode assemblages: an experimental approach. Marine Ecology Progress Series, 181, 227-236.

Snelgrove, P.V.R., \& Butman, C.A. (1994). Animal-sediment relationships revisited: cause versus effects. Oceanography and Marine Biology. An Annual Review, 32, 111-177.

Steyaert, M., Moodley, L., Nadong, T., Moens, T., Soetaert, K., \& Vincx, M. (2007). Responses of intertidal nematodes to short-term anoxic events. Journal of Experimental Marine Biology and Ecology, 345, 175-184.

Sutherland, T.F., Levings, C.D., Petersen, S.A., Poon, P., \& Piercey, B. (2007). The use of meiofauna as an indicator of benthic organic enrichment associated with salmonid aquaculture. Marine Pollution Bulletin, 54, 1249-1261.

Sundbäck, K., Jonsson, B., Nilsson, P., \& Lindström, I. (1990). Impact of accumulating drifting macroalgae on a shallow-water sediment system: an experimental study. Marine Ecology Progress Series, 58, 261-274.

Tolosa, I., Mesa-Albernas, M., \& Alonso-Hernández, C.M. (2009). Inputs and sources of hydrocarbons in sediments from Cienfuegos bay, Cuba. Marine Pollution Bulletin, 58, 1624-1634. 
Urban, E.R., Sundbay, B., Malanotte-Rizzoli, P., \& Melillo, J.M. (2009). Watersheds, bays, and bounded seas. Washington: Island Press.

Vincx, M. (1996). Meiofauna in marine and freshwater sediments. In G.S. Hall, Methods for the examination of of organismal diversity in soils and sediments (187-195). CAB International.

Warwick, R.M., \& Gee, J.M. (1984). Community structure of estuarine meiobenthos. Marine Ecology Progress Series, 18, 97-111.

Warwick, R.M., Platt, H.M., \& Somerfield, P.J. (1998). Free-living marine nematodes. Part III. Monhysterids. Shrewsbury: The Linnean Society of London and The Estuarine and Coastal Sciences Association.

Warwick, R.M., \& Price, R. (1979). Ecological and metabolic studies on free-living marine nematodes from an estuarine mud-flat. Estuarine and Coastal Marine Science, 9, 257-271.

Webb, D.G. (1996). Response of macro- and meiobenthos from a carbon-poor sand to phytodetrital sedimentation. Journal of Experimental Marine Biology and Ecology, 203, 259-271.

Wetzel, M.A., Jensen, P., \& Giere, O. (1995). Oxygen/sulfide regime and nematode fauna associated with Arenicola marina burrows: new insights in the thiobios case. Marine Biology, 124, 301-312.

Widbom, B., \& Elmgren, R. (1988). Response of benthic meiofauna to nutrient enrichment of experimental marine ecosystems. Marine Ecology Progress Series, 42, 257-268. 
Wieser, W. (1953). Die Bezichung swischen Mundhöhlengestalt, Ernährungsweise und Vorkommen bei freilebenden marinen Nematoden. Arkiv för Zoologi, 4, 439484.

Wu, R.S.S. (2002). Hypoxia: from molecular responses to ecosystem responses. Marine Pollution Bulletin, 45, 35-45.

Zajac, R.N., Whitlatch, R.B., \& Thrush, S.F. (1998). Recolonization and succession in soft-sediment infaunal communities: the spatial scale of controlling factors. Hydrobiologia, 375/376, 227-240. 


\section{Figure captions}

Figure 1. Mean values and SD of abiotic factors measured from a field site and from microcosms. A) Organic content $(n=2)$ in sediments. B) Dissolved oxygen from a field site and from microcosms $(n=6)$ at day 30 ; field average is a composite of 23 measures taken in wet seasons during $1991-2001$.

Figure 2. Univariate measures (mean and $S D, n=4$; except for field mean, $n=3$ ) of nematode assemblages in sediments from a field site and from experimental microcosms. Day 0 at the onset of the experiment, and days 4, 15 and 30 after the addition of organic matter in two levels (medium and high).

Figure 3. Multidimensional scaling ordination of samples based on square root transformed data of density of nematode species in sediment from a field site and from microcosms. Number upper symbol indicates days after the onset of the experiment.

Figure 4. Average percentage $(n=4)$ except for field samples $(n=3)$ of feeding types of nematode assemblages in sediments from a field site and from microcosms. Feeding types after Wieser (1953): 1A = selective deposit feeder, $1 \mathrm{~B}=$ non-selective deposit feeder; $2 \mathrm{~A}=$ epigrowth feeder, $2 \mathrm{~B}=$ predator/omnivore. Code of treatments: $\mathrm{F}$ = field samples, $\mathrm{C}=$ control, $\mathrm{M}=$ medium and $\mathrm{H}=$ high . 
Table 1. Mean abundance of nematode species $(n=4)$ in microcosms subjected to three treatments $(C=$ control, $M=$ medium, and $\mathrm{H}=$ high) at four times (days $0,4,15$, and 30 ). Hyphen indicates absence.

\begin{tabular}{|c|c|c|c|c|c|c|c|c|c|c|}
\hline Species & OC & $4 \mathrm{C}$ & $4 \mathrm{M}$ & $4 \mathrm{H}$ & $15 \mathrm{C}$ & $15 \mathrm{M}$ & $15 \mathrm{H}$ & $30 \mathrm{C}$ & $30 \mathrm{M}$ & $30 \mathrm{H}$ \\
\hline Aponema torosus & 26 & 26 & 25 & 6 & 23 & 18 & 7 & - & 2 & - \\
\hline Chromadorita tenuis & - & - & - & 3 & & - & - & - & - & - \\
\hline Cienfuegia cachoi & 32 & 50 & 15 & 15 & 30 & 5 & 11 & 4 & - & 1 \\
\hline Comesoma arenae & - & - & - & - & - & - & - & 4 & 4 & - \\
\hline Cyartonema germanicum & - & - & 2 & - & - & - & - & - & - & - \\
\hline Daptonema sp. & 4 & 22 & - & 6 & - & - & - & - & - & - \\
\hline Desmodora granulata & - & 7 & - & - & - & - & - & - & 1 & - \\
\hline Desmoscolex longisetosus & - & 5 & - & - & 18 & 2 & - & 15 & 1 & 1 \\
\hline Diodontolaimus sabulosus & - & 人 & - & 3 & 4 & - & 2 & 7 & - & 1 \\
\hline Dorylaimopsis punctata & 8 & 33 & - & 0 & 5 & - & 3 & 17 & - & - \\
\hline Gnomoxyala sp. & - & - & - & - & - & - & - & - & 1 & - \\
\hline Halalaimus floridanus & & - & 9 & - & - & 1 & - & - & 1 & - \\
\hline Halichoanolaimus sp. & & - & - & 6 & - & - & - & - & - & - \\
\hline Leptolaimus elegans & & - & 4 & 3 & - & 7 & - & 4 & 4 & 2 \\
\hline Linhystera problematica & - & 5 & - & - & 4 & - & - & 11 & - & - \\
\hline Longicyatholaimus capsulatus & 15 & - & 25 & 4 & - & - & 1 & 13 & - & - \\
\hline
\end{tabular}




\begin{tabular}{|c|c|c|c|c|c|c|c|c|c|c|}
\hline Megadesmolaimus sp. & 4 & 5 & - & 3 & - & 1 & 1 & - & - & . \\
\hline Metachromadora pulvinata & 21 & - & - & - & - & 7 & 6 & - & 7 & 5 \\
\hline Metalinhomoeus filiformis & 216 & 188 & 62 & 47 & 110 & 6 & 10 & 152 & 15 & 1 \\
\hline Paramonohystera proteus & 27 & 21 & 10 & 12 & 21 & 1 & 3 & 9 & 1 & - \\
\hline Parodontophora xenotricha & 32 & 22 & 49 & 29 & 39 & 11 & 11 & 15 & 2 & 4 \\
\hline Pseudoterschellingia ibarrae & - & - & - & - & & - & - & 10 & - & 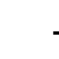 \\
\hline Sabatieria pulchra & 329 & 217 & 212 & 208 & 175 & 5 & 19 & 280 & - & . \\
\hline Setosabatieria hilarula & - & 5 & - & & - & 2 & 1 & - & - & 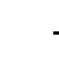 \\
\hline Sphaerolaimus maeoticus & - & - & - & 3 & - & - & - & - & - & . \\
\hline Spirinia parasitifera & 133 & 26 & 46 & 25 & 20 & 42 & 28 & 17 & 35 & 25 \\
\hline Synonchiella hopperi & - & - & 4 & - & - & - & - & - & - & . \\
\hline Terschellingia communis & 55 & 45 & 43 & 31 & 48 & - & - & - & - & . \\
\hline Terschellingia gourbaultae & 137 & 54 & 53 & 58 & 62 & 21 & 21 & 163 & 8 & . \\
\hline Terschellingia longicaudata & 294 & 26 & 116 & 132 & 263 & 37 & 66 & 279 & 24 & 12 \\
\hline Thalassomonhystera sp & & & - & - & 14 & 1 & - & - & 13 & . \\
\hline Viscosia sp. & & 12 & 7 & 6 & - & 2 & - & 4 & - & 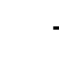 \\
\hline Total & 1335 & 1075 & 681 & 601 & 838 & 169 & 189 & 1005 & 116 & 53 \\
\hline
\end{tabular}


Table 2. Results of statistical comparisons of univariate measures of nematode assemblages. Line separates two ANOVAs (one way and two way crossed). Values of statistic $\mathrm{F}$ and probability are shown. $\mathrm{N}=$ number of nematodes, $\mathrm{S}=$ number of species, $\mathrm{MI}=$ maturity index, $1 \mathrm{~B}=$ non-selective deposit feeding nematodes. Significant results in bold type.

\begin{tabular}{|c|c|c|c|c|}
\hline Factor & $\log N$ & S & $\mathrm{MI}$ & $\% 1 \mathrm{~B}$ \\
\hline Microcosm effect $\left(F_{4,38}\right)$ & $7.3,<0.01$ & $4.9,0.01$ & $4.4,0.01$ & $6.3,<0.01$ \\
\hline Treatment $\left(\mathrm{F}_{2,27}\right)$ & $181.3,<0.01$ & $2.3,0.11$ & $4.0,0.03$ & $31.8,<0.01$ \\
\hline Time $\left(F_{2,27}\right)$ & $116.0,<0.01$ & $12.0,<0.01$ & $9.4,<0.01$ & $40.5,<0.01$ \\
\hline Treatment $x$ time $\left(F_{4,27}\right)$ & $29.4,<0.01$ & $0.5,0.72$ & $2.5,0.07$ & $13.2,<0.01$ \\
\hline
\end{tabular}


Table 3. Outline of studies about effects of organic enrichment on nematode assemblages and/or meiofauna in experimental microcosms.

\begin{tabular}{|c|c|c|c|c|}
\hline Treatment & Sampling event & Effects and ecological remarks & Place, habitat & Reference \\
\hline $\begin{array}{l}\text { Sewage sludge, } 900,2700 \\
\text { and } 9000 \mu \mathrm{C} \mathrm{g}^{-1} \text { sand, } \\
\text { added once time }\end{array}$ & $\begin{array}{l}14,35,55, \text { and } \\
84 \text { days after }\end{array}$ & $\begin{array}{l}\text { Depletion proportional to organic load due } \\
\text { to oxygen availability, presence of } \mathrm{H}_{2} \mathrm{~S} \text { and } \\
\text { heavy metals }\end{array}$ & $\begin{array}{l}\text { UK, unpolluted } \\
\text { intertidal beach, }\end{array}$ & $\begin{array}{l}\text { Sandulli and } \\
\text { Nicola-Giudici, } \\
1989\end{array}$ \\
\hline 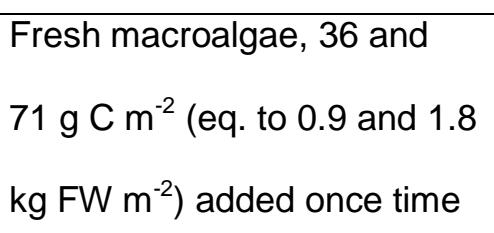 & $\begin{array}{l}1,9,16 \text {, and } 23 \\
\text { days after }\end{array}$ & $\begin{array}{l}\text { No effect in low doses of organic load; } \\
\text { depletion in high doses probably due to } \\
\text { anoxic conditions }\end{array}$ & $\begin{array}{l}\text { Sweden, sandy } \\
\text { sediment from a } \\
\text { shallow }(0.2 \mathrm{~m}) \text { bay }\end{array}$ & $\begin{array}{l}\text { Sundbäck et al., } \\
1990\end{array}$ \\
\hline $\begin{array}{l}\text { Phyto-detritus (several } \\
\text { origins), } 25,75 \text {, and } 200 \mathrm{~g} \mathrm{C} \\
\mathrm{m}^{-2}\end{array}$ & 112 days after & $\begin{array}{l}\text { Reduction in meiofaunal abundance, no } \\
\text { specific response to phyto-detritus. Deposit } \\
\text { feeders were not limited by food availability }\end{array}$ & $\begin{array}{l}\text { Netherlands and } \\
\text { France, intertidal } \\
\text { estuaries }\end{array}$ & $\begin{array}{l}\text { Austen and } \\
\text { Warwick, } 1995\end{array}$ \\
\hline $\begin{array}{l}\text { Phyto-detritus, } 100 \text { and } 200 \\
\mathrm{~g} \mathrm{C} \mathrm{m}^{-2} \text {, added once time }\end{array}$ & $\begin{array}{l}3,12,28 \text { days } \\
\text { after }\end{array}$ & $\begin{array}{l}\text { Positive or no effects to medium dose; } \\
\text { depletion in high dose. Input of organic } \\
\text { matter possible limiting factor }\end{array}$ & $\begin{array}{l}\text { Canada, intertidal } \\
\text { sandy sediment in } \\
\text { salt-mars }\end{array}$ & Webb, 1996 \\
\hline
\end{tabular}




\begin{tabular}{|c|c|c|c|c|}
\hline $\begin{array}{l}\text { Phyto-detritus, 100, } 200 \text { and } \\
400 \mathrm{~g} \mathrm{C} \mathrm{m}^{-2} \text { added several } \\
\text { times }\end{array}$ & 62 days after & $\begin{array}{l}\text { Reduced sediment leads few species able } \\
\text { to survive; dominant species: Terschellingia } \\
\text { longicaudata, and T. communis }\end{array}$ & $\begin{array}{l}\text { UK, intertidal } \\
\text { estuarine } \\
\text { sediments }\end{array}$ & $\begin{array}{l}\text { Schratzberger } \\
\text { and Warwick, } \\
1998\end{array}$ \\
\hline $\begin{array}{l}\text { Phyto-detritus (12.5 - } 400 \mathrm{~g} \\
\mathrm{C} \mathrm{m}^{-2} \text {, added once time) and } \\
\text { physical disturbance }\end{array}$ & 84 days after & $\begin{array}{l}\text { Highest levels of organic enrichment } \\
\text { provoked lower diversity for several levels of } \\
\text { physical disturbance }\end{array}$ & $\begin{array}{l}\text { Norway, subtidal } \\
\text { muddy sand from a } \\
\text { sheltered bay }\end{array}$ & $\begin{array}{l}\text { Austen and } \\
\text { Widdicombe, } \\
2006\end{array}$ \\
\hline $\begin{array}{l}\text { Powdered cow dung, } 20-30 \\
\mathrm{mg} \mathrm{C} \mathrm{g}^{-1} \text { and several heavy } \\
\text { metals }\end{array}$ & 32 days after & $\begin{array}{l}\text { Depletion with organic load and synergistic } \\
\text { effects with metals. Dominant genera: } \\
\text { Dorylaimopsis, Axonolaimus and Theristus }\end{array}$ & $\begin{array}{l}\text { South Africa, } \\
\text { intertidal estuarine } \\
\text { sediment }\end{array}$ & $\begin{array}{l}\text { Gyedu-Ababio } \\
\text { and Baird , } 2006\end{array}$ \\
\hline $\begin{array}{l}\text { Phyto-detritus, } 25 \text { and } 50 \mathrm{mg} \\
\mathrm{C} \mathrm{g}^{-1} \text { DW (eq. to } 400 \text { and } 800 \\
\mathrm{~g} \mathrm{C} \mathrm{m}^{-2} \text { ), added once time }\end{array}$ & $\begin{array}{l}4,15 \text { and } 30 \text { days } \\
\text { after }\end{array}$ & $\begin{array}{l}\text { Depletion and changes in composition, } \\
\text { increase of dominance, dominant species: } \\
\text { T. longicaudata, and Spirinia parasitifera }\end{array}$ & $\begin{array}{l}\text { Cuba, subtidal (12 } \\
\text { m) muddy polluted } \\
\text { sediment }\end{array}$ & Present study \\
\hline
\end{tabular}



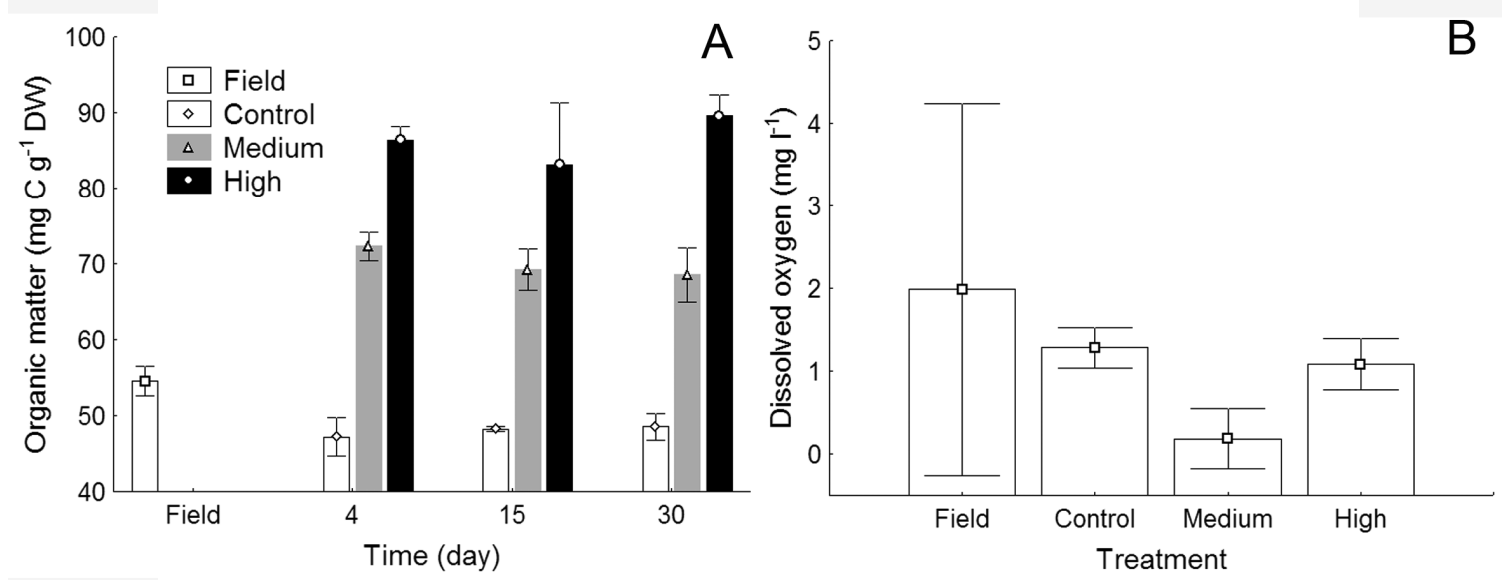

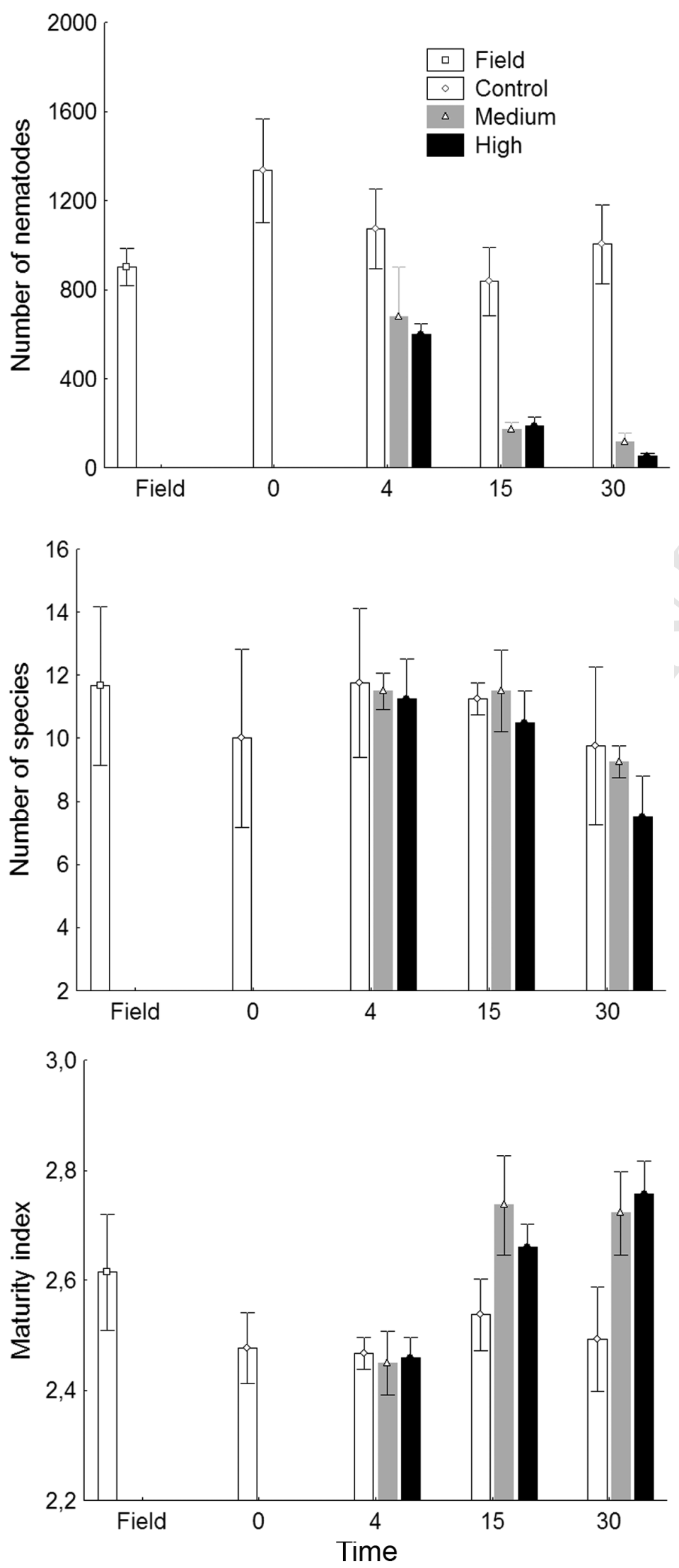


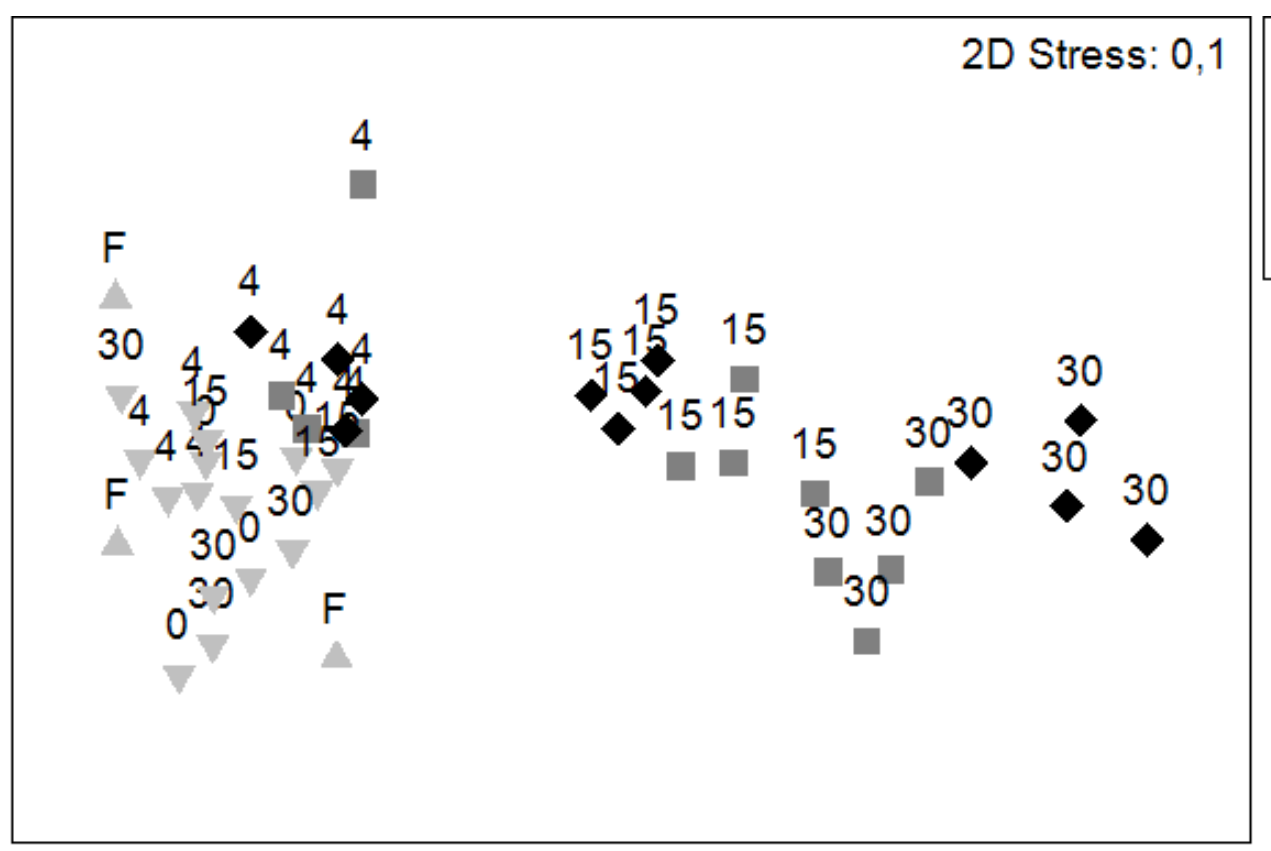




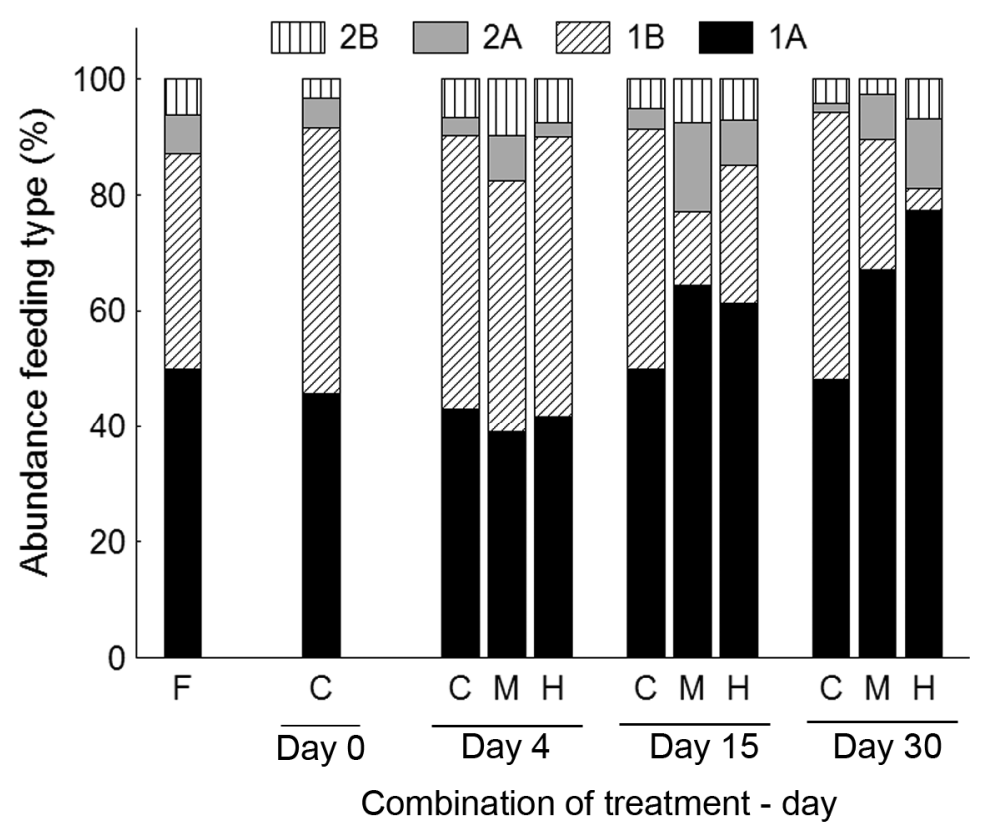

